\title{
The Relationship Between the Resource Curse and Genuine Savings: Empirical Evidence
}

\author{
Adrian Boos ${ }^{1} \&$ Karin Holm-Müller ${ }^{1}$ \\ ${ }^{1}$ Institute for Food and Resource Economics, Chair of Resource and Environmental Economics, University of \\ Bonn, Germany \\ Correspondence: Adrian Boos, Institute for Food and Resource Economics, University of Bonn, Nussallee 21, \\ Bonn 53115, Germany. Tel: 49-172-329-8478. E-mail: adrian.boos@ilr.uni-bonn.de
}

Received: April 20, 2013 Accepted: May 17, 2013 Online Published: May 27, 2013

doi:10.5539/jsd.v6n6p59 URL: http://dx.doi.org/10.5539/jsd.v6n6p59

\begin{abstract}
The objective of this paper is to contribute to research on the determinants of Genuine Savings (GS) by investigating its relationship to the Resource Curse (RC). The substantial empirical evidence confirming that resource-abundant countries are often characterised by slower economic growth can be traced back to the argument that natural resources generate rents independent of economic performance. Recent studies show a negative relation of this so-called RC to GS, a concept that is meant to measure sustainability by considering reinvestments of exactly these rents from natural capital into physical and human capital. Our cross-country analysis examines the influence of determinants and transmission channels identified to cause the RC on GS and its components. Results show that factors leading to the RC are also useful explanatory variables for GS: A clear influence of the share of primary exports in GNI as well as of trade, consumption, quality of institutions, etc. is found. Via the migration of employees and appreciation of the exchange rate, Dutch disease is used to show how the RC works through the different types of capital that make up GS. As a side effect, this combination of dependent variables can explain the RC more comprehensively than GDP growth.
\end{abstract}

Keywords: sustainability, genuine savings, resource curse, natural capital, human capital

\section{Introduction}

"One of the surprising features of modern economic growth is that economies abundant in natural resources have tended to grow slower than economies without substantial natural resources" (Sachs \& Warner, 1995/1997).

This so-called Resource Curse ( $R C$ ) has been documented extensively, showing significant negative relationships between some measure of resource abundance and economic growth, usually the growth rate of per capita GDP (Note 1). The high shares of rents from natural capital depletion in the income of resource abundant countries links the RC to theories on sustainable development, namely to the paradigm of weak sustainability: For lasting and weakly sustainable growth, the reinvestments of these rents in physical and human capital should at least equal the depletion of natural capital, thus holding a country's capital stock constant (Neumayer, 2010).

Genuine Savings (GS) (Note 2) as an indicator for "weak" sustainability measures the difference between the depletion of natural capital and investments in physical and human capital. As expected, it is comparatively low in resource-abundant countries. Hamilton and Clemens (1999) suggest using this relationship to explain the RC. Atkinson and Hamilton (2003) demonstrate that countries will be particularly affected by the RC if natural resources, in combination with inappropriate public expenditure policies, lead to low GS rates. Thus, both papers conclude that GS is a good explanatory for the RC and provides an early warning for future declining economic growth. Consequently, this calls for research on determinants of the GS rate.

However, to a certain extent, it is an artefact to find a relation between an indicator such as GS that is by definition rather low in resource-abundant countries, due to their higher depletion of natural capital and a theoretical construct based on the dependence on income from natural resources. Therefore, in searching for GS determinants, we utilize this proven relation between GS and RC but interpret it differently: A variable that reflects a theory as such suggests itself as endogenous rather than exogenous. We build on this and analyze the determinants of the GS rate as well as its components by using factors already identified in literature to cause the 
RC. We confirm that theories and factors behind the RC are directly related to determinants of the GS rate. We also show how its single components are influenced by the curse.

The main objective of this paper is thus to contribute to the research on determinants of GS by investigating the empirical relationship between the RC and GS. In using Genuine Savings and the change rates of physical, human and natural capital that make up GS as dependent variables, we additionally illustrate that this combination of dependent variables is applicable to show the RC more comprehensively than GDP growth.

To our knowledge there are so far three studies on the determinants of GS and one on genuine income by the research team including Soysa and Neumayer (Neumayer, 2004; Soysa \& Neumayer, 2005; Dietz, Neumayer, \& Soysa, 2007; Soysa, Bailey, \& Neumayer, 2010), whose results on economic openness and political stability are addressed in our empirical analysis. They all regard single aspects of the relationship between the RC and GS. Dietz, Neumayer, and Soysa (2007) for example show the negative influence of corruption on GS in resource-abundant countries. Additionally, Hess (2010) analyzes GS determinants in developing countries and shows a significant influence of the share of fuels, ores, and metals in merchandise exports. However, to our knowledge no empirical study has investigated the relationship between the RC and GS systematically.

We methodically build on the study by Neumayer (2004): He reproduces the original RC study by Sachs and Warner (1995/1997) (Note 3) using the growth rate of genuine income and shows the same negative effect on GDP. His dependent variable originates from the World Bank's GS dataset but only deducts the depreciation of physical capital and parts of natural capital depletion from GDP. Additionally, GS subtracts consumption as well as damage from $\mathrm{CO}_{2}$ emissions. However, the most important difference is the inclusion of investment in human capital by adding education expenditures. The aim of this paper is not to discuss these extensions. We think GS is useful despite some drawbacks, offset by its public availability and international comparability (Note 4). Nevertheless, our paper will add to the discussion of GS since its determinants are not sufficiently understood so far. A better understanding will support interpretation, criticism and further development. In using the intuitive relationship between this indicator and the $\mathrm{RC}$, we contribute to its explanation.

Our study also starts with regressions analogous to the original by Sachs and Warner (1995/1997), with GS as dependent variable. After showing that the RC still holds true for GS, even over an extended period, we expand the regressions by investigating the effects on the single capital types and by adding more explanatory variables. We show that GS is more closely related to the RC than GDP. The following chapter surveys the theoretical background; then we describe the empirical analysis and discuss the results in view of these theories.

\section{The Theoretical Relationship Between the RC and GS}

The RC denotes the effect that countries richly endowed with natural resources often show slower economic growth. Research behind it seeks to find explanations for this paradox, varying the measures for resource-abundance from study to study but reporting a similar core message: Higher dependency on the income from natural resources causes slower per capita GDP growth, more or less independent from the other economic or policy variables used (Sachs \& Warner, 2001). Gelb (1988) and Auty (1993) show the political difficulty for governments to save (and not spend) the rents from natural capital and the lack of institutions to reinvest this income efficiently. The problem of insufficient reinvestment of resource-related profits links the RC and the theories behind it to the paradigm on weak sustainability and its indicator GS.

Weak sustainability is based on the assumption that different forms of capital are in principle substitutable and that only a country's total capital stock is important to "maintain the capacity to provide non-declining utility for infinity" (Neumayer, 2010). The so-called "Hartwick rule" (Hartwick, 1977) provides a "rule of thumb" for weak sustainability: Keep a country's total capital stock at least constant to allow for sustained consumption over time and therefore "invest into all forms of capital at least as much as there is depreciation of all forms of capital" (Neumayer, 2010). This can be traced to the concept of "Hicksian income" (Hicks, 1946), which states that a country should only consider the interest on its capital stock as income. While the latter may be consumed, the stock has to stay constant to be as well off over time as at the beginning. GS illustrates basically this mix of consumption and savings, theoretically seen as the reinvestment of depleted natural capital into other forms of capital, the net investment into the total capital stock (Dietz, Neumayer, \& Soysa, 2007).

Resource-abundant countries deplete more natural capital and need to reinvest more to achieve positive GS rates. However, since the first case studies by Gelb (1988) and Auty (1993), we know that most resource abundant countries consume their income from resource exports rather than reinvest these rents. Theoretically, these countries live on their capital stock and decrease future welfare. Using their natural capital for present welfare erodes the basis for development by not investing this income into physical capital such as infrastructure or 
human capital such as education. Since this also results in decreasing future GDP, negative GS could be seen as early sign for a possible curse in resource-abundant countries (Atkinson \& Hamilton, 2003).

By dividing the analysis into the three forms of capital, it can be shown in more detail how theories and explanations behind the RC influence the respective GS components. In the following, we explain the calculation method of GS and link the different parts directly to the theories behind the RC: GS as an indicator for weak sustainability was developed by Pearce and Atkinson (1993), Hamilton (1994), Pearce, Hamilton, and Atkinson (1996) and Hamilton and Clemens (1999). Based on traditional gross national income (GNI), GS includes the change rates of the three forms of capital, physical $\left(\mathrm{K}_{\mathrm{P}}\right)$, human $\left(\mathrm{K}_{\mathrm{H}}\right)$ and natural $\left(\mathrm{K}_{\mathrm{N}}\right)($ Note 5$)$ :

$$
\begin{gathered}
G S=(G N I-C P-C G+N C T)-\text { depreciation of } K P+\text { education expenditures }(\delta K H) \\
- \text { natural resource depletion }(\delta K N)
\end{gathered}
$$

Gross national income $(\mathrm{GNI})$ minus private $\left(\mathrm{C}_{\mathrm{P}}\right)$ and public (governmental) consumption $\left(\mathrm{C}_{\mathrm{G}}\right)$ plus net current transfers (NCT) refers to gross national savings (GNS). This is based on the aforementioned rule that only an optimal mix of consumption and savings (where income is principally divided into these two alternatives) can maximize intertemporal welfare (Dietz, Neumayer, \& Soysa, 2007). NCT comprise all exchanges with foreign countries of goods and services as well as income and financial items without a quid pro quo (World Bank, 2011). The resulting GNS are theoretically seen as gross investment in physical capital.

However, physical capital also depreciates over time and subtracting this so-called consumption of already existing produced capital from GNS leads to net national savings (NNS), which - at least theoretically - is equivalent to net investment in physical capital $\left(\boldsymbol{\delta} \mathbf{K}_{\mathbf{P}}\right)$ (Hamilton \& Clemens, 1999).

While NNS already contains the physical part of total education expenditures including investment in school buildings, other investments in human capital - such as the purchase of school books or payment of teachers' salaries - are traditionally treated as consumption (Hamilton, 2006). Therefore, GS adds current operating expenditures on education as a rather crude approximation for investment in human capital $\left(\delta \mathbf{K}_{\mathbf{H}}\right)$.

Consumption of natural capital $\left(\boldsymbol{\delta} \mathbf{K}_{\mathrm{N}}\right)$ is considered by subtracting the depletion of different natural resources and the damages from $\mathrm{CO}_{2}$ emissions (Hamilton \& Clemens, 1999; Hamilton, 2006): The depletion of natural resources is composed of the rents of energy and mineral resources and that of net forest depletion (Note 7). These rents demonstrate the change in the natural resource asset value associated with their extraction over the accounting period and therefore the change in the natural capital stock (Atkinson \& Hamilton, 2007). Social costs from $\mathrm{CO}_{2}$ emission damages are assumed to be US\$20 (in 1990) per emitted metric ton (Frankhauser, 1994). However, air pollution is not considered a direct depletion of a country's natural capital stock, rather a transboundary depletion of all forms of capital (Atkinson \& Hamilton, 2007). Therefore, an analysis bringing the $\mathrm{RC}$ and GS together should differentiate between natural capital and damages by carbon dioxide.

Since the depletion of energy, mineral and wood resources is calculated using actual world market prices, the volatility of primary commodity prices substantially influences the rents making up $\delta \mathrm{K}_{\mathrm{N}}$ within GS without changing the actual amounts depleted in tons (Boos \& Holm-Müller, 2012). In resource-abundant countries the depletion of natural capital $\delta \mathrm{K}_{\mathrm{N}}$ primarily goes into exports while a large part of investment in $\mathrm{K}_{\mathrm{P}}$ is determined by imported consumption and capital goods (Barbier, 2007). However, due to these volatile terms of trade (ToT), investments in $K_{P}$ suffer from planning uncertainty and a higher elasticity of demand for imported consumption than investment. Therefore increases in $\mathrm{K}_{\mathrm{N}}$ turn out to be higher than in $\mathrm{K}_{\mathrm{P}}$ (Blattman, Hwang, \& Williamson, 2007; Koren \& Tenreyro, 2007). Therefore, the ratio of $\delta \mathrm{K}_{\mathrm{N}}$ to $\delta \mathrm{K}_{\mathrm{P}}$ changes in the same direction as a country's ToT, since these represent the ratio between the price indices for exports and imports and - in contrast to GDP growth - GS rates are negatively influenced by increasing ToT (Boos \& Holm-Müller, 2012).

This is directly related to the most famous exogenous explanation from the RC literature, Dutch disease (DD): a boom in the natural resource sector - either induced by the discovery of new reserves or increasing world market prices - results in higher rents within the calculation of $\delta \mathrm{K}_{\mathrm{N}}$ and increasing export revenues. This additional income on the one hand increases the demand for goods from the other sectors and thus changes the relation of consumption and investment. On the other hand it causes the real exchange rate to appreciate. The additional demand for manufactured goods has to be met by imports, increasing competition in this sector (Davis, 1995) and further facilitated by the higher exchange rate (Krugman, 1987).

While manufacturing relies on world markets, the prices and therefore wages in the service sector rise due to additional demand and therefore employees move from manufacturing to the resource and service sector (Auty, 2007). While this decreases investments in $\mathrm{K}_{\mathrm{H}}$, due to more unskilled production processes in these two sectors, 
on the other hand the service sector is more labour-intensive and requires less investment in $K_{P}$ (Dietz, Neumayer, \& Soysa, 2007). The capital-intensive mining sector attracts high investments in $K_{P}$ but still crowds out investment in more productive sectors. In summary, due to DD effects, $\delta \mathrm{K}_{\mathrm{N}}$ increases while reinvestments in the other two forms of capital are negatively influenced (Gylfason, 2001).

These exogenous explanations could result in a higher integration into world markets, in traditional economics an important factor for growth (Irwin \& Terviö, 2002). Trade openness influences $\delta K_{N}$ via income (rents) from exports, $\delta \mathrm{K}_{\mathrm{P}}$ via imports for consumption and capital goods and the public budget via trade taxes. However, openness typically leads to a diversification of the economy, thus it is positively related to GS (Soysa \& Neumayer, 2005, 2010).

Nonetheless, openness or exposure through integration into world markets is related to the political system itself and its transmission channels through the quality of institutions. Not only do various studies demonstrate that resource-abundant countries are less democratic (Ross, 2001; Soysa \& Neumayer, 2005), Soysa and Neumayer (2010) also show that democracy has a positive influence on GS, because democratic governments deplete natural capital less and invest more in human capital. However, democracy has to be supported by strong institutions:

Weak rule of law decreases GS through insecure structures for daily economic behavior and investment due, for example, to an unreliable judiciary system or insecure property rights. The level of corruption - either private or public - has the worst effect on investment behavior and GS rates in the study by Dietz, Neumayer, and Soysa (2007). Resource rents constitute an easily attainable source of income and corrupt agents use these rents for consumption rather than investment. However, corruption is not only built on rents, political patronage to sinecure interest groups has similar negative effects on GS. Due to high transaction costs for private investors and decreasing public investment opportunities through higher publicly paid wages, a weak quality of bureaucratic services contaminated by patronage influences GS negatively. Finally, all of these factors influence macroeconomic and public expenditure policies, according to Atkinson and Hamilton (2003) the most important conjunction between the RC and GS, since they affect the composition of consumption and investment.

In summary, literature reveals the most important factors leading to $\mathrm{RC}$ as: higher incentives for consumption than investment, volatility, DD effects and quality of institutions. In the following, we consider the theoretical relations between the RC and GS empirically. We start by explaining our proceedings and close with a comprehensive discussion of the results from the view of these theoretical explanations.

\section{Empirical Analysis}

\subsection{Research Design}

Most data in this work stems from the World Bank's online Data Catalog for World Development Indicators and Global Development Finance (Note 8). We extract GDP, GS and its components (physical, human and natural capital as well as carbon dioxide damage), primary exports and total trade as well as data on consumption, interest and exchange rates, share of employees in the service sector and remittances from abroad in order to reflect theoretical influences described in the chapter above. Additionally, we use data on the investment share of real GDP from the Penn World Tables 6.3 (Heston, Summers, \& Aten, 2009) and indices for the rule of law, corruption and bureaucratic quality from the International Country Risk Guide by the Political Risk Service (PRS) (Note 9). In order to insert the quality of the political system, we drew the most respected democracy index Polity IV from the Colorado State University Polity IV Project (Note 10). Which series we finally use is described in the respective regression.

Following Neumayer (2004), our first step is repeating the basic regressions in which Sachs and Warner $(1995 / 1997)$ analyze the RC for the first time in a detailed cross-country analysis. This original study uses average data from 1970 to 1990 for a sample between 71 and 87 developing and industrialized countries depending on the applied explanatory variables. It shows that an increase in the average share of exports of primary products in GNI results in slower average growth rates of GDP per capita independent of the additional explanatory variables. Neumayer (2004) confirms that this also holds true for the period from 1970 to 1998 as well as for growth in genuine income (Note 11).

Since we use a longer period, 1970 to 2008 , we have to replace some of the explanatory variables from these two original studies with analogous ones from a theoretical viewpoint, explained below. Table 1 in the next chapter, shows the results of six regressions in six columns. We start by mimicking the original model, then replace the 
endogenous with the average rate of GS and then investigate the different types of capital. In Table 2, we summarize the regressions with additional variables.

In our first analysis (results in Table 1, regression 1), we regress the average annual growth rate of GDP per capita between 1970 and 2008 (GDP7008) on the initial GDP per capita in 1970 and the average share of exports of primary products (agricultural, mineral and energy resources) in GNI between 1970 and 2008 (SXP7008). Contrary to Sachs and Warner (1995/1997), we use the average share over the whole period as our proxy for resource dependence, since the single base year 1970 used in the original study loses its applicability when analyzing across forty years.

For the integration into world markets, we apply the average share of total trade (imports and exports) in GDP the typical proxy in empirical literature (Barro \& Sala-i-Martin, 2004) - between 1970 and 2008 (TRADE7008). The openness index used by Sachs and Warner (1995/1997) cannot be expanded beyond the year 1990. As in the original analyses, the investment share of real GDP (INV7007) from the Penn World Tables (Heston, Summers, \& Aten, 2009) provides a proxy for the handling of natural resource income: the investment in produced capital.

The rule of law index from 1982 used by Sachs and Warner (1995/1997) is today only available from 1984 on in the International Country Risk Guide. However, instead of only a single year we use the average index value between 1984 and 2008 (RL8408). The average growth rate of the net barter terms of trade index between 1980 and 2008 (TOT8008) by the World Bank completes the first regression.

In regression 2, GDP is replaced by GS. We regress the average rate of GS between 1970 and 2008 in \% of GNI (GS7008) on the initial GS from the individual years for which it is first available (different years depending on the country), and the same five additional explanatory variables as in column 1 . In regression 3 , we use NNS in \% of GNI as dependent variable for the average change rate in physical capital between 1970 and 2008 (KP7008). The average education expenditures in \% of GNI comprise the average investment in human capital between 1970 and 2008 (KH7008) in regression 4. In regression 5 and 6, we differentiate the consumption of natural capital in the actual average depletion of natural resources $(\mathbf{K N 7 0 0 8 )}$, which relates the RC directly to GS, and the damages by carbon dioxide (CARB7008), due to the argument that $\mathrm{CO}_{2}$ emissions are not only a direct depletion of a country's natural capital, rather a transboundary one of all capital forms. By regressing the three forms of capital on their initial values and the same explanatory variables as in regressions 1 and 2 , we show the influence of these determinants on the different components of GS. To our knowledge, only Soysa, Bailey, and Neumayer (2010) have used similar dependents, regressing on another set of determinants.

In Table 2, we add variables applicable as proxies for additional theories and hypotheses behind the RC, such as DD. Dependent variables, initial values, the average share of primary exports (SXP7008), total trade (TRADE7008), and the growth rate of the terms of trade index (TOT8008) remain constant as in table 1. However, in Table 2, we complement the share of primary exports with easily attainable exogenous source of income by remittances received from migrant workers (REMI7008), since most resource-abundant countries also depend on them.

In Table 1, we test the argument that GS are net investments in the total capital stock of a country and therefore the investment share of real GDP (INV7007) theoretically has a positive influence on KP and the total GS rate. In Table 2, we then test the counterpart of this argument, that a higher share of consumption should affect GS negatively and exchange investment by the average consumption share of real GDP (CON7008) (due to multi-collinearity we cannot use both in the same regression).

Following arguments by Atkinson and Hamilton (2003), who state that macroeconomic policies and public expenditures have an important impact on the distribution of investment and consumption and therefore also on the relationship between the RC and GS, we use the average real interest rate (INT7008) as a proxy for a country's macroeconomics and as the average price for investment or compensation for savings, respectively.

As a proxy for DD's so-called spending effect, which states that additional income from resource exports should appreciate the real exchange rate, we use its average growth rate between 1970 and 2008 (EXCH7008). The hypothesis of the movement effect - that workers migrate from traditional sectors either to work in the booming resource or growing service sector - is proxied by the average share of employees in the service sector to total employment (EMSER7008).

As Dietz, Neumayer, and Soysa (2007) show, there are other important institutional factors influencing the rate of GS besides the rule of law. To have a more general institutional variable, we combine the index for the rule of law from Table 1 with indices for corruption and bureaucratic quality - all surveyed in the same scale by PRS and create averages from these three indices from 1984 to 2008 (IQ8408). Multi-collinearity prevents us from 
using the individual indices together; therefore we additionally show the results separately. However, since the other coefficients only change slightly, we report the results for RL8408, COR8408 and BQ8408 separately and not the entirely new models. In the last row of Table 2, we exchange IQ8408 with the average value of the democracy index Polity IV (POL7008), since we know from Soysa, Bailey, and Neumayer (2010) that democratic development influences GS rates positively. This index includes opportunities for political expression and gaining executive power through competitive elections, as well as its transfer and constraints.

\subsection{Results and Discussion}

In regression 1, we see that the main results by Sachs and Warner (1995/1997) and Neumayer (2004) also hold for this longer period and for a larger sample. Detailed conclusions for GDP growth can be found in these studies. All variables apart from terms of trade stay significant with the same signs as in the original studies. It seems that terms of trade growth loses its positive link to GDP growth in the period between 1980 and 2008 used in our regressions compared with the period from 1970 until 1990 analyzed by Sachs and Warner (1995/1997). Beside the average growth rate of the net barter terms of trade index (TOT8008), we also checked for the average index values and the average volatility rate of world market commodity prices between 1970 and 2008 without significant results. In the original study by Sachs and Warner (1995/1997), it was only slightly significant at the $10 \%$ level (and no longer significant at any level in the study by Neumayer (2004)). Average international commodity prices were subject to $10.5 \%$ fewer fluctuations in the longer period from 1980 to 2008 used in our analysis. Therefore, this insignificance might be simply due to a lack of variance.

Regression 2 assigns the exogenous variables to the average rate of GS between 1970 and 2008 (GS7008). For most variables, the same signs apply but the initial values have a positive influence since GS rates are measured in \% of GNI and not as growth rates. While a higher initial GDP level results in smaller growth rates, there is an intuitive relationship between the initial GS rate and its average value over the next 39 years. By nature of its calculation, the average GS rate between 1970 and 2008 is more negatively influenced by the share of primary exports in GNI than GDP: A $10 \%$ increase in the average share of primaries (SXP7008) is estimated as decreasing the average GS between 1970 and 2008 by around $1.4 \%$ compared with $0.3 \%$ for GDP growth (in the original 21-year analysis this is more than 1\% (Sachs \& Warner, 1995/1997)). However, it has to be kept in mind that this is sound to a certain limit since the GS rate is around $8 \%$ of GNI while the growth rate of GDP per capita is averagely around $2 \%$ over the whole sample.

As expected, the share of primary exports in GNI between 1970 and 2008 (SXP7008) increases the depletion of natural capital (in regression 5) but shows no significant relationship to the change rates of the two other forms of capital. The difference of the SXP7008 coefficients in 2 and 5 can be interpreted as the reinvestment realized in the two other forms of capital, as $\delta \mathrm{K}_{\mathrm{N}}$ is subtracted in the calculation of GS. Looking at these numbers reveals that reinvestment is small, mirroring the discussion that resource-dependent countries " $[\ldots]$ need to invest more of the proceeds of natural capital depletion into the formation of other forms of capital than they currently do" (Dietz \& Neumayer, 2006).

As Soysa and Neumayer (2005) show, the economic openness of a country, here reflected by the integration into world markets (TRADE7008), positively influences the rate of GS. While the share of trade in GDP shows a significant positive influence on all calculation parts of GS in Soysa, Bailey, and Neumayer (2010), we estimate only a slightly positive influence on investment in physical capital (KP7008) and therefore the total GS rate; the integration into world markets results in diversification away from exclusively living from natural capital and decreases the prices of imported capital goods that comprise the basis for investment in KP. A $10 \%$ higher share of total trade in GDP increases GS by around $0.4 \%$.

The investment share of real GDP (INV7007) influences GDP growth positively in the original studies as well as in regression 1. However, while the growth rate of genuine income in the analysis by Neumayer (2004) is also positively related to increasing investments, table 1 shows its only link besides GDP to the damages from $\mathrm{CO}_{2}$ emissions (in regression 6). That is, higher investments increase emissions, which could be related to investments in the manufacturing sector. Interestingly, INV7007, which measures the average gross investment in physical capital is not estimated to have an influence on KP7008 - theoretically intended to show the net investment in physical capital - or on GS itself.

Higher index values for a country's rule of law (RL8408) decrease $\mathrm{CO}_{2}$ emissions, increase the investment in human capital (KH7008) and are therefore related to a higher total GS rate (regressions 2, 4 and 6). The average rule of law from 1984 to 2008 influences even the growth rate of GDP per capita more than in the original study by Sachs and Warner (1995/1997), which only uses the index value for one year in 1982. Interestingly, the period average from 1982 to 1995 applied in the analysis by Neumayer (2004) does not show any effect on GDP 
or genuine income. Clearly, for the 1980s through the mid-1990s, rule of law was not as important for economic growth and sustainable development as it was for the remaining period until 2008.

The only different sign compared to the original study by Sachs and Warner (1995/1997) appears in the growth rate of terms of trade (TOT8008). Their analysis finds it positively influencing GDP growth. The authors assign this to the Prebisch-Singer thesis arguing that decreasing terms of trade of primary commodity exporters slow economic growth (Prebisch, 1950; Singer, 1950). This is due to the composition of GS that terms of trade influence it negatively (in regression 2): KN (in regression 5) is positively affected since an increase of terms of trade means higher prices for exports at least relative to imports. Higher resource prices result in increasing depletion, either through real increases in depleted amounts or by the calculation method through world market prices. An increase of KN decreases GS as soon as there is no sufficient reinvestment. Therefore, a higher average growth rate of a country's terms of trade results on average in smaller GS.

Table 1. Dependent variables: GDP, genuine savings and its components 1970-2008

\begin{tabular}{lcccccc}
\hline & 1 & 2 & 3 & 4 & 5 & 6 \\
\hline \multirow{2}{*}{ Initial } & GDP7008 & GS7008 & KP7008 & KH7008 & KN7008 & CARB7008 \\
& -0.0004 & 0.28 & 0.23 & 0.63 & 0.31 & 0.39 \\
SXP7008 & $(-3.57)^{* * *}$ & $(4.12)^{* * *}$ & $(4.0)^{* * *}$ & $(11.1)^{* * *}$ & $(3.51)^{* * *}$ & $(6.1)^{* * *}$ \\
& -3.05 & -14.38 & 6.2 & -0.1 & 16.01 & 0.34 \\
TRADE7008 & $(-2.66)^{* * *}$ & $(-2.21)^{* *}$ & $(1.16)$ & $(-0.1)$ & $(3.13)^{* * *}$ & $(1.24)$ \\
& 0.82 & 3.87 & 2.76 & -0.1 & -0.82 & -0.06 \\
INV7007 & $(2.4)^{* *}$ & $(2.16)^{* *}$ & $(1.72)^{*}$ & $(-0.49)$ & $(-0.42)$ & $(-0.71)$ \\
& 3.24 & 13.47 & 5.1 & 1.42 & -9.78 & 1.06 \\
RL8408 & $(2.07)^{* *}$ & $(1.59)$ & $(0.68)$ & $(1.42)$ & $(-1.52)$ & $(2.75)^{* * *}$ \\
& 0.52 & 1.49 & 0.58 & 0.22 & -0.66 & -0.09 \\
TOT8008 & $(3.49)^{* * *}$ & $(2.36)^{* *}$ & $(1.01)$ & $(2.95)^{* * *}$ & $(-1.29)$ & $(-2.9)^{* * *}$ \\
& 0.02 & -0.75 & 0.1 & -0.0004 & 0.84 & 0.007 \\
N & $(0.56)$ & $(-3.17)^{* * *}$ & $(0.43)$ & $(-0.016)$ & $(4.19)^{* * *}$ & $(0.61)$ \\
Adjusted R2 & 107 & 103 & 104 & 104 & 99 & 108 \\
F-statistic & 0.32 & 0.48 & 0.28 & 0.67 & 0.65 & 0.42 \\
\hline
\end{tabular}

*** Significant at 0.01 level, $* *$ at 0.05 level,

* at 0.10 level (t-values in parentheses)

In the extended regressions in Table 2, we keep SXP7008, TRADE7008 and TOT8008. They show the same signs as in Table 1 with minor differences: Despite more control variables, all of which are discussed in the following, the share of resource exports in GNI (SXP7008) influences GDP as well as GS more negatively and significantly than in Table 1. Additionally, there is a highly significant negative influence of resource exports on investments in physical capital (KP7008) (in regression 9). Although we did not find the same result in Table 1 this was theoretically expected due to the argument that investments in the resource sector crowd out those in more productive sectors. Therefore, a higher share of income from the export of natural resources in GNI decreases investments in physical capital at least relatively to the share of additional consumption. The above argued diversification by higher openness is additionally mirrored by the negative influence of TRADE7008 on the depletion of natural capital in regression 11. The positive link between trade and GS is higher and more significant, as in Table 1.

Moreover, we use average net incoming remittances in \% of GDP between 1970 and 2008 (REMI7008) to control for other exogenous income sources besides primary exports in order to ensure that the observed effects really stem from the dependence on the exports of natural resources. We also tested foreign aid and development 
assistance unsuccessfully, theoretically also negatively influencing the spending behavior in resource-dependent countries. All of these exogenous factors do not prevent the export of primary goods from being significant. Choosing remittances was logical since a great deal of resource-abundant countries also depend on this other foreign income source (López Córdova \& Olmedo, 2006). Remittances are positively linked to GS through high investments in KP. Recipient households are proven to invest in private education and in small, productive businesses. However, the mere level of investment in KP also predicts high additional investments in, for example, the manufacturing sector.

Due to the argument that consumption should decrease GS since consumed income is not invested into a country's capital stock, we replace the insignificant share of investment from Table 1 with the average total consumption share of real GDP between 1970 and 2008 (CON7008). Increased consumption is significantly negatively related to GDP growth as well as the rate of GS (in regressions 7 and 8). Although both coefficients for GDP7008 and GS7008 have to be interpreted carefully due to partial identity problems (Note 12), these results support the theories behind the RC and GS concerning the consumption of natural capital: As expected, higher consumption negatively influences reinvestment in KP (in regression 9) and therefore the total rate of GS. Since increasing consumption is also statistically related to a decrease in the depletion of KN (in regression 11), the difference between these two coefficients almost count for the negative one of total GS (regression 8).

Following Atkinson and Hamilton (2003), we also tested public consumption due to their findings that "countries that have primarily used resource abundance to finance current consumption have fared far less well" than the ones whose governments "have used resource abundance to finance investments". Our results show no significant difference between public or total consumption. Therefore, we keep total consumption in the regressions based on the fact that private consumption also increases as the income elasticity of demand for the consumption of manufactured goods is higher than for investment in capital goods (Barbier, 2007).

Public expenditure policies dividing the governmental budget into consumption and investment depend on macroeconomic policies as do private saving and investment decisions. Therefore, in addition to the share of consumption, we use the average real interest rate (INT7008) as a proxy for a country's macroeconomics. As the average compensation for savings or the market price for investments respectively, this influences GS positively. Higher interest rates cause an increase in savings but there is no significant sign that smaller interest rates result in investment in other capital forms than natural. However, the negative link between the interest rate and KN7008 could serve as an argument that higher interest rates result in investments other than mining.

The average growth rate of the official exchange rate (EXCH7008), following the DD hypothesis of appreciation due to the increasing income influx from natural resource exports (or other income sources such as remittances), influence investment in KP (in regression 9) and total GS (in regression 8) negatively. Possible reasons for this include increasing consumption shares in income when imports become cheaper as well as a decreasing governmental budget for investments from trade taxes in domestic currency. Since Gylfason, Herbertsson, and Zoega (1999) state that not only the pure appreciation has a negative impact on economic growth, but also uncertainties resulting from exchange rate volatility, we checked for this using a volatility index without significant results.

The other DD effect, the migration of workers from the manufacturing into the resource and the service sector shows through our proxy - the share of employment in the service sector in total employment (EMSER7008) the expected negative influence on KP (in regression 9). This is logical since the service sector needs less investment in KP, but we did not find the expected negative effect on KH. Following the crowding out argument in the theory of the DD - as explained in chapter 2 - worker migration should also decrease $\mathrm{KH}$ (in regression 10). Additionally, the higher negative coefficient on total GS compared with the one on KP indicates a negative background effect not shown in this model. However, since our sample not only includes resource-dependent but also industrialized countries with sophisticated service sectors such as finance or consulting that involve higher average investments in $\mathrm{KH}$, this cancels any significant effects. Nevertheless, the positive link to the depletion of $\mathrm{KN}$ (in regression 11) additionally supports the theory of the DD.

As the only study known so far using GS as dependent variable in combination with explanatory variables for the RC, Dietz, Neumayer, and Soysa (2007) show that in interaction with resource-abundance, a lack of institutional quality is a serious factor for low rates of GS. They use a panel analysis to demonstrate that corruption is one of the major determinants negatively influencing GS and that a stronger rule of law also has a positive influence on GS. All three indices for corruption, rule of law and bureaucratic quality used by this analysis are measured in the same way (Note 13). Therefore, we put all three together to one index of institutional quality from 1984 to 2008 (IQ8408): As expected, higher institutional quality is linked to less 
depletion of KN (in regression 11) and higher education expenditures (in regression 10), showing that the total GS rate (in regression 8) is positively influenced by the quality of institutions. Clearly, good institutions are related to a greater diversification of the economy beyond depleting natural resources, which entails preserving parts of this stock and investing more in human capital for sophisticated production processes and services.

Table 2. Dependent variables: GDP, genuine savings and its components 1970-2008

\begin{tabular}{|c|c|c|c|c|c|c|}
\hline & 7 & 8 & 9 & 10 & 11 & 12 \\
\hline & GDP7008 & GS7008 & KP7008 & KH7008 & KN7008 & CARB7008 \\
\hline \multirow[t]{2}{*}{ Initial } & -0.0006 & 0.22 & 0.14 & 0.57 & 0.31 & 0.61 \\
\hline & $(2.52)^{* *}$ & $(3.39)^{* * *}$ & $(2.9)^{* * *}$ & $(9.1)^{* * *}$ & $(2.65)^{* * *}$ & $(7.26)^{* * *}$ \\
\hline \multirow[t]{2}{*}{ SXP7008 } & -5.82 & -35.85 & -12.01 & 0.84 & 25.77 & 0.47 \\
\hline & $(-4.24) * * *$ & $(-4.94)^{* * *}$ & $(-2.66)^{* * *}$ & $(0.91)$ & $(4.54)^{* * *}$ & (1.19) \\
\hline \multirow[t]{2}{*}{ TRADE7008 } & 0.86 & 5.81 & 1.42 & 0.1 & -3.82 & -0.003 \\
\hline & $(2.21)^{* *}$ & $(2.9) * * *$ & (1.16) & $(0.39)$ & $(-2.49)^{* *}$ & $(-0.03)$ \\
\hline \multirow[t]{2}{*}{ TOT8008 } & 0.005 & -0.57 & -0.24 & -0.002 & 0.22 & 0.003 \\
\hline & $(0.1)$ & $(-2.44)^{* *}$ & $(-1.53)$ & $(-0.05)$ & $(1.23)$ & $(1.41)$ \\
\hline \multirow[t]{2}{*}{ REMI7008 } & 14.13 & 92.5 & 102.72 & 5.49 & 3.9 & 3.97 \\
\hline & $(2.64)^{* *}$ & $(3.64)^{* * *}$ & $(6.03)^{* * *}$ & (1.52) & $(0.21)$ & $(2.58)^{* *}$ \\
\hline \multirow[t]{2}{*}{ CON7008 } & -10.18 & -40.55 & -68.24 & 0.09 & -24.64 & -0.73 \\
\hline & $(-5.36)^{* * *}$ & $(-4.57)^{* * *}$ & $(-10.95)^{* * *}$ & $(0.07)$ & $(-3.78) * * *$ & $(-1.3)$ \\
\hline \multirow[t]{2}{*}{ INT7008 } & -0.21 & 20.68 & 3.83 & -1.17 & -12.85 & 0.11 \\
\hline & $(-0.13)$ & $(2.74)^{* * *}$ & $(0.75)$ & $(-1.11)$ & $(-2.29)^{* *}$ & $(0.25)$ \\
\hline \multirow[t]{2}{*}{ EXCH7008 } & -0.02 & -0.18 & -0.15 & 0.01 & 0.02 & 0.0004 \\
\hline & $(-1.44)$ & $(-2.39)^{* *}$ & $(-2.9) * * *$ & $(0.48)$ & $(0.4)$ & $(0.1)$ \\
\hline \multirow[t]{2}{*}{ EMSER7008 } & -0.64 & -13.75 & -8.0 & 0.28 & 6.41 & -0.38 \\
\hline & $(-0.72)$ & $(-3.45)^{* * *}$ & $(-3.0)^{* * *}$ & $(0.49)$ & $(2.22)^{* *}$ & $(-1.57)$ \\
\hline \multirow[t]{2}{*}{ IQ8408 } & 0.13 & 0.42 & -0.22 & 0.14 & -0.51 & -0.01 \\
\hline & $(1.97)^{*}$ & $(1.95)^{*}$ & $(-1.59)$ & $(4.5)^{* * *}$ & $(-2.81)^{* * *}$ & $(-1.0)$ \\
\hline \multirow[t]{2}{*}{ RL8408 } & 0.54 & 1.24 & -0.31 & 0.3 & -0.1 & -0.03 \\
\hline & $(3.4) * * *$ & $(2.11)^{* *}$ & $(-0.79)$ & $(3.22)^{* * *}$ & $(-2.1)^{* *}$ & $(-0.87)$ \\
\hline \multirow[t]{2}{*}{ COR8408 } & 0.27 & 1.45 & -0.9 & 0.39 & -2.11 & -0.03 \\
\hline & (1.39) & $(2.1)^{* *}$ & $(-1.97)^{*}$ & $(3.65)^{* * *}$ & $(-3.7)^{* * *}$ & $(-0.73)$ \\
\hline \multirow{2}{*}{ BQ8408 } & 0.22 & 2.39 & -1.1 & 0.74 & -2.63 & -0.1 \\
\hline & $(0.78)$ & $(2.58) * *$ & $(-1.76)^{*}$ & $(5.97)^{* * *}$ & $(-3.64) * * *$ & $(-1.43)$ \\
\hline \multirow[t]{2}{*}{ POL7008 } & -0.01 & 0.41 & 0.02 & 0.05 & -0.51 & -0.002 \\
\hline & $(-0.31)$ & $(4.02)^{* * *}$ & $(0.22)$ & $(3.45)^{* * *}$ & $(-4.87)^{* * *}$ & $(-0.37)$ \\
\hline $\mathrm{N}$ & 85 & 84 & 85 & 84 & 80 & 85 \\
\hline Adjusted R2 & 0.45 & 0.63 & 0.7 & 0.72 & 0.73 & 0.51 \\
\hline F-statistic & 7.76 & 14.85 & 20.14 & 22.12 & 21.88 & 9.84 \\
\hline
\end{tabular}

*** Significant at 0.01 level, $* *$ at 0.05 level, $*$ at 0.10 level (t-values in parentheses).

We also examine the single indices, only reporting their results and not the entirely new models, since the remaining outcome does not change substantially. In Table 1, rule of law (RL8408) positively influences GS through a decrease in the depletion of $\mathrm{KN}$ and higher investments in KH. Corruption (COR8408) shows the same signs but a stronger influence and an additional positive correlation to the investment in KP (in regression 9). Neither the coefficient nor the significance is high but it seems interesting that corruption could be related to further investment. Possible explanations are so-called "white elephants", investment projects with sinecures for certain interest groups but negative social surplus (Robinson \& Torvik, 2005). While higher corruption, especially rent-seeking behavior, is directly related to higher depletion of KN (in regression 11), it also decreases investments in $\mathrm{KH}$ (in regression 10) and therefore the total GS rate (in regression 8). Bureaucratic quality (BQ8408) - related to corruption through patronage structures that hand official positions to interest groups influences GS and its components slightly more in the same direction. In total, GS rates are positively influenced by higher quality institutions, but conversely to the study by Dietz, Neumayer, and Soysa (2007), bureaucratic quality plays the biggest role followed by corruption. This is not entirely unexpected due to large inefficient 
bureaucratic apparatuses created to serve various interest groups in resource-abundant countries, which increase the ratio of consumption through more publicly paid employees.

Additionally, due to evidence by Soysa, Bailey, and Neumayer (2010) that democracy influences GS rates positively, we exchange the quality of institutions with the democracy index Polity IV (POL7008). Soysa, Bailey, and Neumayer (2010) also use the individual components of GS as dependent variables, showing that democracies deplete less natural capital and invest more in human capital, as we also show in regressions 10 and 11. In total, the democratic status of a country positively influences its GS rate.

\section{Summary}

In using the average growth rate of GDP per capita, we show that the main results by Sachs and Warner (1995/1997) hold true, also for the period from 1970 to 2008. By nature of its calculation, GS is intuitively more closely related to the exports of natural resources. Our analysis estimates a decrease between $1.4 \%$ (Table 1) and $3.5 \%$ (Table 2) in the average GS rate for a $10 \%$ increase in the average share of primary exports in GNI between 1970 and 2008. For most of the control variables, the same signs apply as in the original studies. However, the growth rate of terms of trade decreases GS due to the composition of exported KN and imported consumption goods as well as capital goods as reinvestments in KP. The consumption share of real GDP is highly significantly, negatively related to the rate of GS since higher consumption decreases reinvestments. Public expenditure policies dividing the governmental budget into consumption and investment as well as private saving and investment decisions depend partially on interest rates. Higher interest rates cause an increase in savings and have a positive effect on the total GS rate. The appreciation of the exchange rate influences GS negatively through decreasing investments in KP caused by an increase in imported consumption. Migration of workers from the manufacturing sector into the service sector shows the expected negative influence on KP since the service sector requires less investment in produced capital. The positive link to the depletion of KN supports the theory of Dutch disease. Table 3 shows an overview of all significant coefficient signs from both tables.

As expected, better institutional quality is linked to less depletion of natural capital and higher education expenditures, showing that the total GS rate is positively influenced by the quality of institutions. Surprisingly, bureaucratic quality plays a more important role than in earlier studies. For the period investigated by our analysis, corruption-related patronage structures handing official positions to interest groups seem to influence GS and its components more than corruption itself or a functioning rule of law. Increased quality in bureaucratic services and institutions negatively influences reinvestment in KP since most countries with high quality institutions already have large stocks in produced capital. However, countries with stable institutions and democratic structures deplete less natural capital and invest more in human capital and therefore have higher GS rates.

In summary, independent of the control variables used, the average share of primary exports in GNI between 1970 and 2008 negatively influence the average rate of GS as an indicator for sustainable development. Integration into international trade, its mere size as well as the proportion between exports and imports play an important role here, equal to the comparison between investment and consumption. Even if it is difficult to show Dutch disease effects empirically, higher ratios of consumption in additional income, an appreciation of the exchange rate as well as a higher ratio of employment in the service sector influences GS rates negatively. In contrast, democracy, a functioning rule of law, low rates of corruption and the quality of the bureaucratic apparatus influence sustainable development rather positively. 
Table 3. Overview of regression results*

\begin{tabular}{|c|c|c|c|c|c|c|}
\hline & GDP7008 & GS7008 & KP7008 & KH7008 & KN7008 & CARB7008 \\
\hline Initial & - & + & + & + & + & + \\
\hline SXP7008 & - & - & - & & + & \\
\hline TRADE7008 & + & + & + & & - & \\
\hline ТОТ 8008 & & - & & & + & \\
\hline REMI7008 & + & + & + & & & + \\
\hline INV7007 & + & & & & & + \\
\hline CON7008 & - & - & - & & - & \\
\hline INT7008 & & + & & & - & \\
\hline EXCH7008 & & - & - & & & \\
\hline EMSER7008 & & - & - & & + & \\
\hline IQ8408 & + & + & & + & - & \\
\hline RL8408 & + & + & & + & - & \\
\hline COR8408 & & + & - & + & - & \\
\hline BQ8408 & & + & - & + & - & \\
\hline POL7008 & & + & & + & ـ & \\
\hline
\end{tabular}

* Signs listed for coefficients that are at least significant at $10 \%$ level.

\section{Conclusions}

On the one hand, we show that the curse of natural resources does not only retard economic growth but also depreciates a country's capital stock and thereby its basis for future growth. We confirm that theories and factors behind the RC are assignable to the concept of GS. We also show how single components of a country's capital stock are influenced by the RC. Table 3 sums up possible determinants of this index concept for "weak" sustainability, suggesting further research in this direction, especially whether or not (and how) countries dependent on natural resource exports are able to realize positive GS rates. Therefore, structures for reinvestment in physical and human capital at least equalling the size of depleted natural capital have to be identified.

On the other hand, in using Genuine Savings and the changes in physical, human and natural capital as dependent variables, we additionally show that this combination of dependent variables is a more appropriate approach to explain the RC than regressions on GDP alone. We strongly recommend using a combination of GDP and GS as dependents in further studies on the RC, since not only the selection of explanatory variables is important to prove theoretical concepts.

Where our results differ from those derived from studies on GDP, the theoretical background offers an explanation. On the whole, the estimated results meet our expectations. We gain several insights into the mechanism of the RC via the division into the three capital types. However, we worked with a broad basis, testing several variables in order to confirm our theory and method. We do not dig deeper into special relationships apart from one example of Dutch disease. Therefore, we strongly recommend further investigation of GS and its components for two reasons: Shrinking GS constitute an early sign for eroding the capital stock for sustained development. Even without observable RC effects, this should be considered an economic warning for the respective country. Using the three types of capital allows learning more about the mechanisms behind the RC. Knowing these in more detail might enable us to better prevent economies from suffering. It facilitates gathering more a priori information for case studies. Overall, further research in this field supports better policy recommendations.

\section{Acknowledgements}

The authors wish to thank Nina Karstens and Julia Hoffmann from the Institute for Food and Resource Economics, University of Bonn, for their helpful comments and corrections.

\section{References}

Atkinson, G., \& Hamilton, K. (2003). Savings, Growth and the Resource Curse Hypothesis. Part special issue: Links between poverty and environment degradation in Latin America. World Development, 31, 1793-1807. http://dx.doi.org/10.1016/j.worlddev.2003.05.001

Atkinson, G., \& Hamilton, K. (2007). Progress along the path: evolving issues in the measurement of genuine $\begin{array}{llll}\text { saving. Environmental and Resource Economics, } & \text { 37(1), }\end{array}$ 
http://dx.doi.org/10.1007/s10640-007-9114-7

Auty, R. M. (1993). Sustaining development in mineral economies: The resource curse thesis. London, England; New York, NY: Routledge. http://dx.doi.org/10.4324/9780203422595

Auty, R. M. (2007). The resource curse and sustainable development. In G. Atkinson, S. Dietz, \& E. Neumayer (Eds.), Handbook of sustainable development (pp. 207-219). Cheltenham, Northampton: Edward Elgar.

Barbier, E. (2007). Natural resources and economic development (2nd ed.). Cambridge, NY: Cambridge University Press.

Barro, R. J., \& Sala-I-Martin, X. (2004). Economic growth (2nd ed.). Cambridge, NY: MIT Press.

Blattman, C., Hwang. J., \& Williamson, J. G. (2007). Winners and losers in the commodity lottery: The impact of terms of trade growth and volatility in the Periphery 1870-1939. Journal of Development Economics, 82(1), 156-179. http://dx.doi.org/10.1016/j.jdeveco.2005.09.003

Bolt, K., Matete, M., \& Clemens, M. (2002). Manual for Calculating Adjusted Net Savings. Washington, D.C.: World Bank Environment Department.

Boos, A., \& Holm-Müller, K. (2012). A theoretical overview of the relationship between the resource curse and genuine savings as an indicator for "weak" sustainability. Natural Resource Forum - A United Nations Sustainable Development Journal, 36(3), 145-159. http://dx.doi.org/10.1111/j.1477-8947.2012.01456.x

Davis, G. A. (1995). Learning to love the Dutch disease: Evidence from the mineral economies. World Development, 23, 1765-1779. http://dx.doi.org/10.1016/0305-750X(95)00071-J

Dietz, S., \& Neumayer, E. (2006). A critical appraisal of genuine savings as an indicator of sustainability. In P. Lawn (Ed.), Sustainable development indicators in ecological economics: Current issues in ecological economics (pp. 117-135). Cheltenham, Northampton: Edward Elgar.

Dietz, S., Neumayer, E., \& Soysa, I. (2007). Corruption, the resource curse and genuine saving. Environment and Development Economics, 12(1). 33-53. http://dx.doi.org/10.1017/S1355770X06003378

Frankel, J. A. (2010). The Natural Resource Curse: A Survey. NBER Working Paper Series No. 15836. Retrieved from http://www.nber.org/papers/w15836

Frankhauser, S. (1994). Evaluating the Social Costs of Greenhouse Gas Emissions. The Energy Journal, 15(2), $157-184$.

Gelb, A. H. (1988). Oil windfalls. Blessing or curse? New York: Oxford University Press.

Gylfason, T. (2001). Natural resources, education, and economic development. European Economic Review, 45, 847-859. http://dx.doi.org/10.1016/S0014-2921(01)00127-1

Gylfason, T., Herbertsson, T. T., \& Zoega, G. (1999). A Mixed Blessing (Natural Resources and Economic Growth). Macroeconomic Dynamics, 3, 204-225. http://dx.doi.org/10.1017/S1365100599011049

Hamilton, K. (1994). Green adjustments to GDP. Resources Policy, 20(3), 155-168. http://dx.doi.org/10.1016/0301-4207(94)90048-5

Hamilton, K. (2006). Where is the wealth of nations? Measuring capital for the 21st century. Washington, D.C.: The World Bank.

Hamilton, K., \& Clemens, M. (1999). Genuine Savings Rates in Developing Countries. The World Bank Economic Review, 13, 333-356. http://dx.doi.org/10.1093/wber/13.2.333

Hartwick, J. M. (1977). Intergenerational Equity and the Investing of Rents from Exhaustible Resources. The American Economic Review, 67, 972-974.

Hess, P. (2010). Determinants of the adjusted net saving rate in developing economies. International Review of Applied Economics, 24, 591-608. http://dx.doi.org/10.1080/02692170903426070

Heston, A., Summers, R., \& Aten B. (2009). Penn World Table Version 6.3. Center for International Comparisons of Production, Income and Prices at the University of Pennsylvania, Retrieved from https://pwt.sas.upenn.edu/php_site/pwt63/pwt63_form.php

Hicks, J. (1946). Value and capital: An inquiry into some fundamental principles of economic theory (2nd ed.). Oxford: Clarendon Press.

Irwin, D. A., \& Terviö M. (2002). Does trade raise income? Evidence from the twentieth century. Journal of International Economics, 58(1), 1-18. http://dx.doi.org/10.1016/S0022-1996(01)00164-7 
Koren, M., \& Tenreyro S. (2007). Volatility and Development. The Quarterly Journal of Economics, 122(1), 243-287. http://dx.doi.org/10.1162/qjec.122.1.243

Krugman, P. (1987). The narrow moving band, the Dutch disease, and the competitive consequences of Mrs. Thatcher. Notes on trade in the presence of dynamic scale economies. Journal of Development Economics, 27(1-2), 41-55. http://dx.doi.org/10.1016/0304-3878(87)90005-8

López Córdova, E., \& Olmedo A. (2006). International remittances and development. Existing evidence, policies and recommendations. Buenos Aires: Institute for the Integration of Latin America and the Caribbean.

Neumayer, E. (2004). Does the "Resource Curse" hold for Growth in Genuine Income as Well? Part special issue: Land reform and conflict in southern Africa: Lessons from Zimbabwe's experience. World Development, 32, 1627-1640. http://dx.doi.org/10.1016/j.worlddev.2004.05.005

Neumayer, E. (2010). Weak versus strong sustainability. Exploring the limits of two opposing paradigms (3nd ed.). Cheltenham, Northampton: Edward Elgar.

Pearce, D., Hamilton, K., \& Atkinson, G. (1996). Measuring sustainable development: progress on indicators. Environment and Development Economics, 1(01), 85-101. http://dx.doi.org/10.1017/S1355770X00000395

Pearce, D. W., \& Atkinson, G. (1993). Capital theory and the measurement of sustainable development: an indicator of "weak" sustainability. Ecological Economics, 8, 103-108. http://dx.doi.org/10.1016/0921-8009(93)90039-9

Prebisch, R. (1950). The Economic Development of Latin America and its Principal Problems. Lake Success, NY: The United Nations.

Robinson, J. A., \& Torvik, R. (2005). White elephants. Journal of Public Economics, 89, 197-210. http://dx.doi.org/10.1016/j.jpubeco.2004.05.004

Ross, M. L. (1999). The Political Economy of the Resource Curse. World Politics, 51, 297-322. http://dx.doi.org/10.1017/S0043887100008200

Ross, M. L. (2001). Does Oil Hinder Democracy? World Politics, 53, 325-361. http://dx.doi.org/10.1353/wp.2001.0011

Rosser, A. (2006). The Political Economy of the Resource Curse: A Literature Survey. IDS Working Paper, 268, Brighton: University of Sussex.

Sachs, J., \& Warner, A. M. (1995/1997). Natural Resource Abundance and Economic Growth. NBER Working Paper Series No. 5398. Retrieved from http://www.nber.org/papers/w5398

Sachs, J., \& Warner, A. M. (2001). The curse of natural resources. European Economic Review, 45, 827-838. http://dx.doi.org/10.1016/S0014-2921(01)00125-8

Singer, H. W. (1950). The Distribution of Gains between Investing and Borrowing Countries. The American Economic Review, 40, 473-485.

Soysa, I., Bailey, J., \& Neumayer E. (2010). Free to Squander? Democracy and Sustainable Development, 1975-2000. In R. A. Matthew (Ed.), Global environmental change and human security (pp. 262-289). Cambridge, NY: MIT Press.

Soysa, I., \& Neumayer E. (2005). False Prophet, or Genuine Savior? Assessing the Effects of Economic Openness on Sustainable Development, 1980-1999. International Organization, 59, 731-772. http://dx.doi.org/10.1017/S0020818305050253

Van der Ploeg. (2011). Natural Resources: Curse or Blessing? Journal of Economic Literature, 49, 366-420. http://dx.doi.org/10.1257/jel.49.2.366

World Bank. (2011). The Changing wealth of nations: Measuring Sustainable Development in the New Millennium, Washington, D.C: World Bank.

\section{Notes}

Note 1. Literature on this paradox offers a wealth of theoretical and empirical explanations ranging from the volatility of terms of trade and Dutch disease effects to the quality of institutions and the political system of a country. For literature reviews see for example Ross (1999), Rosser (2006), Frankel (2010), Van der Ploeg (2011), or Boos \& Holm-Müller (2012). 
Note 2. "Adjusted net savings" in World Bank terms.

Note 3. Sachs \& Warner (1995/1997) show for the first time in their renowned cross-country analysis that an increase in primary exports results in a decline of the growth rate of GDP per capita.

Note 4. For detailed discussions see Atkinson \& Hamilton (2003) or Neumayer (2010).

Note 5. Detailed calculation descriptions and definitions can be found in Bolt, Matete, \& Clemens (2002), Hamilton (2006), or World Bank (2011).

Note 6. http://data.worldbank.org/indicator/BN.TRF. CURR.CD

Note 7. Resource Rent $=$ Production Volume * (International Market Price - Average Unit Production Costs).

Energy depletion covers crude oil, natural gas and coal.

Mineral depletion refers to bauxite, copper, iron, lead, nickel, phosphate, tin, zinc, gold and silver.

Net forest depletion refers to roundwood harvest minus natural growth; this is set to zero if growth exceeds depletion.

Note 8. http://data.worldbank.org/data-catalog

Note 9. http://www.prsgroup.com/CountryData.aspx

Note 10. http://www.systemicpeace.org/polity/ polity4.htm

Note 11. In Neumayer (2004) genuine income is GDP minus the depreciation of produced and natural capital. Since this study by Neumayer (2004), the World Bank publishes genuine income as adjusted net national income in its World Development Indicators: http://data.worldbank. org/data-catalog

Note 12. In both, somewhere along the calculation path, consumption is used as content and therefore, within regressions 1-2 and 7-8, this appears on both sides of the equation.

Note 13. Data is from the International Country Risk Guide by the Political Risk Service: http://www.prsgroup.com/CountryData.aspx

\section{Copyrights}

Copyright for this article is retained by the author(s), with first publication rights granted to the journal.

This is an open-access article distributed under the terms and conditions of the Creative Commons Attribution license (http://creativecommons.org/licenses/by/3.0/). 